\title{
Criopreservação de espermatozóides equinos comparando duas curvas de congelamento combinadas com diluentes comerciais: uma análise laboratorial*
}

\author{
PAULA BARROSTERRACIANO
}

\author{
Elizabeth Obino Cirne-Lima (Orientador - UFRGS)
}

Eneder Rosana Oberst (Co-orientador - UFRGS)

Banca: Eduardo Pandolfi Passos (UFRGS). Rodrigo Costa Mattos (UFRGS). Marilise Mesquita Horn (UERGS).

Durante o processo de criopreservação de sêmen, os espermatozóides sofrem alguns danos que resultam na diminuição da fertilidade deste. O presente estudo foi realizado a fim de avaliar o efeito da utilização, combinada de duas curvas de congelamento com dois diluentes comerciais sobre a criopreservação de sêmen equino. Foram analisados 20 ejaculados. As amostras foram avaliadas pela motilidade progressiva e total do sêmen pós-descongelamento e pela integridade e funcionalidade da membrana dos espermatozóides. A combinação entre curva automatizada e Botu-Crio ${ }^{\circledR}$ apresentou as maiores médias, nas análises de motilidade total $(55,53 \%)$ e progressiva $(17,25 \%)$, após o descongelamento. O diluente Botu-Crio ${ }^{\circledR}$, isoladamente, apresentou também os melhores resultados quando foram realizadas as análises de integridade (CFDA/PI) e funcionalidade de membrana pelo teste hiposmótico.

Descritores: Sêmen, equino, criopreservação, espermatozóide, fertilidade.

*Dissertação de Mestrado n.461 (Especialidade: Reprodução Animal). 53f. Programa de Pós-Graduação em Ciências Veterinárias [www.ufrgs.br/ ppgcv]. Faculdade de Veterinária, Universidade Federal do Rio Grande do Sul (UFRGS), Porto Alegre/RS. CORRESPONDÊNCIA: P.B. Terraciano [paulaterraciano@gmail.com]. 


\title{
Cryopreservation of equine spermatozoa comparing different freezing rates combined with comercial extenders: laboratorial analysis**
}

\author{
PAULA BARROSTERRACIANO
}

\author{
Elizabeth Obino Cirne-Lima (Adviser - UFRGS) \\ Eneder Rosana Oberst (Co-adviser - UFRGS)
}

Committee: Eduardo Pandolfi Passos (UFRGS). Rodrigo Costa Mattos (UFRGS). Marilise Mesquita Horn (UERGS).

During semen cryopreservation, sperm cells were submitted to some deleterious events leading to membrane damage which result in fertility decrease. This study was designed to compare the effects of two freezing techniques (conventional and automated), their freezing rates and the use of two commercial extenders as cryoprotectants (FR- $5^{\circledR}$ and Botu-Crio ${ }^{\circledR}$ ) on the total and progressive motility, integrity and functionality of spermatic membranes during the cryopreservation of equine semen. Twenty ejaculates were analyzed. The total and progressive motility of fresh and post-thawing semen samples were evaluated by the patterns assays. The function of plasmatic membrane was measured by the hipoosmotic swelling test. The integrity of plasmatic membrane was evaluated using CFDA/PI fluorescent probes. There were significant differences between the two freezing techniques and/or between cryoprotectants for all assessed parameters. The combined used between Botu$\mathrm{Crio}^{\circledR}$ and automated curves showed better results in total and progressive post-thawing motility. The extender Botu-Crio ${ }^{\circledR}$, alone, showed better results in order to preserve the membrane integrity and function.

Key words: Semen, equine, cryopreservation, sperm cell, fertility.

**Master's Thesis \#461 (Field: Animal Reproduction). 53p. Graduate Program in Veterinary Sciences [www.ufrgs.br/ppgcv]. Faculdade de Veterinária, Universidade Federal do Rio Grande do Sul (UFRGS), Porto Alegre/Brazil. CORRESPONDENCE: P.B. Terraciano [paulaterraciano@gmail.com]. 